UDC: $930=111$

DOI: https://doi.org/10.31470/2616-6275-2021-5-188-196

Дочка Владімірова-Аладжсва

Керівник відділу нумізматики та епіграфіки

Національний інститут археології та музей

Болгарська Академія Наук

(Софія, Болгарія)
Dochka Vladimirova-Aladzhova

Dr. Prof. Head of the Department of Numismatics and Epigraphy

National Archaeological Institute with Museum,

Bulgarian Academy of Sciences

(Sofia, Bulgaria)

ORCID: 0000-0002-0718-5007

aladzhovadochka@gmail.com

\title{
UNKNOWN SEAL OF EMPEROR JUSTIN I (518-527) FROM SERDICA
}

\section{НЕВЦДОМА ПЕЧАТКА ІМПЕРАТОРА ЮСТІНА І (518-527) ІЗ СЕРДИКИ}

\section{Summary.}

The paper examines a seal of Emperor Justin I (518-527). It has the following description:

Obverse: Beardless bust with a nimbus of Emperor Justin I, opposite, with a helmet and chlamys. Around the image an inscription in clockwise direction:

N IVSTI NVSPPAVG = D(ominus) n(oster Justinus p(er)petus Aug(ustus)

Reverse: Victoria standing across with a wreath in each hand, in the bottom left field a small So far there is not known bulla of this ruler from Bulgaria and because of that some questions arise when identifying the specimen from Serdica. The inscription on the newly discovered seal showed that the bulla belonged to Justin, but it is not clear if it is Justin I (518-527) or Justin II (565-578). The image on the obverse differs from the known images of Justin I and Justin II. It is smaller and occupies part of the nucleus, while in the published so far the size of the bullotirium is larger than the nucleus itself. The inscription of the copy from Serdica is clearly legible, but the letters and the image are small, which distinguishes this seal from the known so far. The difference is obvious also in the reverse, in which Victoria does not follow the model of the image from the molybdenums of Justinian I and Justin II, but her image is close to that of the seals of Anastasius I, and even could be said that it completely copies it. The characteristics of the seal, its inscription and images are different from the ones of the copies of Justin II, which is a serious reason to attribute it to the time of Emperor Justin I, which makes it currently unique of this type.

Other evidence of life in Serdica from the time of Emperor Justin I (518 - 527) are the coins discovered. In Serdica the most numerous are the coins of 40 nummi, followed by those of 20 nummi, which are almost two times less than the large denomination. The number of the specimens of 10 and 5 nummi is equal, but is less 
than the number of the large denominations. As mints, the coins from Constantinople predominated, followed by coins from Nicomedia, Antioch and Cyzicus. Among the regular coins were found two imitations of folles of Justin I, which imitate the production of the mint of Constantinople from this period. These coins, found together with the official ones used in the Byzantine state, show that they were accepted by the financial authorities as a regular payment tool. Two gold coins of Justin I are discovered in Serdica I - a solidus found at the eastern fortress wall and a tremis from the excavations at the northeastern tower.

The new seal of Emperor Justin I presented in the article and the coins discovered by this ruler in Serdica show the significant role of the city during this period.

Key words: seal, sphragistics, Emperor Justin I, gold coin, copper coins, imitations of follis, Serdica

\section{Анотація.}

В статті розглянуто печатку візантійського імператора Юстина I (518-527), яка має такий опис:

Аверс: бюст безбородого імператора Юстина I; анфас: зображення імператора у шоломі з німбом, який одягнений у хламіду. Навколо образу імператора кругова легенда за годинниковою стрілкою: N IVSTI NVSPPAVG = D(ominus) n(oster Justinus p(er)petus Aug(ustus).

Реверс: Вікторія, стоячи, із вінками у кожній руці, у нижньому лівому полі малий хрест. Таким чином, ия знахідка на даний час становить невідому буллу изього правителя з Болгарії, тому виникають деякі питання щзодо ї̈ ідентифікащії. Написи на нововиявленій печатщуі вказують на приналежність булли до Юстина, але чітко не встановлено до Юстина I (518-527) чи Юстина II (565-578). Зображення на аверсі відрізняється від відомих зображень Юстина I та Юстина II. Воно менше та займає частину центру, тоді як на опублікованих, зазвичай, розмір булаторію більше ніж иентральна частина. Написи на зразку із Сердики чітко читаються, але літери та зображення малі, щзо суттєво відрізняє июю печатку від уже відомих.

Очевидна різниця також на реверсі, де Вікторія не відповідає зразкам зображення з молібденів Юстиніана I та Юстина II, але ї̈ зображення наближене до деяких печаток Анастасія I та, можна зауважити, практично копіює його. Характеристики печатки, ї̈ написи та зображення відрізняються від відомих аналогів за Юстина II, щуо дає серйозні підстави датувати ї̈ часом імператора Юстина I, щзо робить ї̈ унікальною для цьього типу на сьогодні.

Іншим свідченням життєдіяльності в Сердиці за часів імператора Юстина I (518-527) стали виявлені монети. Найбільш численними серед знахідок Сердики виявилися монети номіналом 40 нуммій, дещяо менше виявлено 
монет номіналом 20 нуммій, щз вдвічі менше за великі номінали. Кількість екземплярів номіналом 10 та 5 нуммій рівна, але менша за кількість монет більшого номіналу. За монетними дворами домінують монети карбування Константинополя, далі по кількості - монети Нікомедї, Антіохії та Кізіка. 3-посеред монет державного карбування виявлено також дві імітації фолісів Юстина I, які наслідують продукиії монетного двору в Константинополі изього періоду. Виявлення цүих монет разом із монетами офіційного карбування, щуо використовувались у Візантї, свідчить про їх затвердження фінансовими органами влади як регулярного інструмента обігу. У Сердиці знайдені також дві золоті монети Юстина I - солід, виявлений у східній фортечній стіні, та тре місій, знайдений під час розкопок у північно-східній вежі.

Описані у статті нові монети та печатка імператора Юстина I зі знахідок із Сердики свідчать про значну роль міста в цей період.

\section{Ключові слова: печатка, сфрагістика, імператор Юстин I, золота} монета, імітації мідних фолісів, Сердика

During rescue archeological excavations on the site of a metro line in the center of the modern city of Sofia (ancient Serdica), a seal of Emperor Justin I (518-527) was identified among the discovered sphragistic materials. It has the following description:

Obverse: Beardless bust with a nimbus of Emperor Justin I, opposite, with a helmet and chlamys. Around the image an inscription in clockwise direction:

. .N IVSTI NVSPPAVG = D(ominus) n(oster Justinus p(er)petus Aug(ustus)

Reverse: Victoria standing across with a wreath in each hand, in the bottom left field a small isosceles cross ${ }^{1}$. Along the circumference a well-preserved grainy circle.

Lead. 18/12 mm; weight: 8.27 g (Fig. 1a, b)

The seals of Justin I in the world collections are rear, and in their identification there are various opinions that define them as bullae of Justinian $\mathrm{I}^{2}$ or those of Justin II. In the Hermitage collection, there is no identified seal of Justin I, but only one of Justin $\mathrm{II}^{3}$. In the Dumbarton Oaks collection, one anonymous seal of Justin I was identified and two of Justin $\mathrm{II}^{4}$ for one of which ${ }^{5}$ the identification was questioned by W. Zeibt, who attributed the seal to Justin $\mathrm{I}^{6}$. So far there is not known bulla ${ }^{7}$ of this ruler from Bulgaria and because of that some questions arise when identifying the specimen from Serdica. The inscription on the newly discovered seal showed that the bulla belonged to Justin, but it is not clear if it is Justin I (518-527) or Justin II (565-

\footnotetext{
${ }^{1}$ Due to a damage of the blank, the cross on the right is not visible.

${ }^{2}$ Соколова 2007, 25

${ }^{3}$ Ibidem.

${ }^{4}$ Nesbit, Morrisson 2009, 14-15.

${ }^{5}$ Zacos,Veglery 1972, no. 5; http://www.doaks.org/resources/seals/byzantine-seals/BZS.1955.1.4238

${ }^{6}$ Seibt 1975, 209.

7 Jordanov 2012, 57-76.
} 
578). The image on the obverse differs from the known images of Justin I and Justin II. It is smaller and occupies part of the nucleus, while in the published so far the size of the bullotirium is larger than the nucleus itself. The inscription of the copy from Serdica is clearly legible, but the letters and the image are small, which distinguishes this seal from the known so far. The difference is obvious also in the reverse, in which Victoria does not follow the model of the image from the molybdenums of Justinian I and Justin II, but her image is close to that of the seals of Anastasius $\mathrm{I}^{1}$, and even could be said that it completely copies it. The characteristics of the seal, its inscription and images are different from the ones of the copies of Justin II, which is a serious reason to attribute it to the time of Emperor Justin I, which makes it currently unique of this type.

Emperor Justin I (518-527), like his predecessor Anastasius I, had an ideological connection with Serdica. Justin I supported the Orthodoxy and the decisions of the Nicene Creed, undertook a widespread abolition of Monophysitism and persecution of its followers ${ }^{2}$. At the same time, he resumed his relationship with Rome, and for this purpose a council was convened in 518 A.D. in Constantinople, at which the Chalcedon norms of the faith were officially restored and applied to the entire empire. Along with that continued the persecution of the followers of the Monophysitism and the supporters of Emperor Anastasius $\mathrm{I}^{3}$. Evidence of this is the information from Marcellinus Comes: "The governor of the palace Amancius and the cubicularius [i.e. the emperor's bodyguards] Andrew, Mizahel, and Ardabur were captured as patrons of the Manicheans and as traitors of emperor Justin. Two of them Amancius and Andrew - were slaughtered, and Mizahel and Ardabur were sent into exile in Serdica." Theocritus, an associate of Amancius, was imprisoned and died there, crushed by a huge stone. He has been prepared by Amacius for emperor ${ }^{4}$. In this case, Serdica was preferred as a place of exile ${ }^{5}$ by Justin I, who regarded this city, its citizenship and the city government as his supporters, because of the well-known, from the time of Anastasius I, Orthodox orientation i.e. adoption and veneration of the Chalcedon canons. Probably the persecution of the followers of Anastasius I began in 528 A.D., with the accession to the throne of the new emperor Justin $\mathrm{I}^{6}$, and the seal from Serdica is an evidence for the period of religious confrontation from the first decades of the VI century.

The absence of direct information regarding the fate of Serdica from the first decades of the VI century is a fact that can be interpreted as an indication that the city in this period has not experienced serious cataclysms. The argument is not convincing and it could not be explained that a city, capital of a province, remained unaffected by

\footnotetext{
${ }^{1}$ Nesbit, Morrisson 2009, 6.

2 Данчева-Василева 2017, 42

${ }^{3}$ Jones 1964, 268-269

4 Латински извори за българската история I, 1958, 317 - Marcellinus Comes, 516, 99.

${ }^{5}$ The city is not mentioned in other sources as a place of exile.

${ }^{6}$ Данчева- Василева 2017, 43.
} 
the processes within the western borders of the Eastern Roman Empire and specifically on the Balkan Peninsula ${ }^{1}$ i.e. the Slavic invasions of the Balkan Peninsula followed by the permanent settlement of numerous Slavic tribes ${ }^{2}$. These events transformed the Empire and left their mark on all spheres of the social, political and spiritual life.

The first major Slavic invasion dates back to the beginning of the reign of Emperor Justin I (518-527), when one of the Slavic tribes, the Antes, invaded the territory south of the Danube, but was repulsed by the strategos of Thrace, German ${ }^{3}$. The attacks continued during the reign of Emperor Justinian I, and in 531 A.D. the Slavs, together with the Huns and Avars, have conducted their first major invasion south of the Danube, inflicting irreparable damage to the Romans ${ }^{4}$. An independent invasion of the Slavs on the Balkan Peninsula followed in 535 A.D., directed to Thrace, when they captured a large number of Romans. There are not enough data about the invasions from 531 and 535 A.D. which could link them to Serdica ${ }^{5}$.

Other evidence of life in Serdica from the time of Emperor Justin I (518 - 527) are the coins discovered. These are 63 specimens, of which 59 are made of bronze and four are made of gold 6 .

During the reign of this emperor, the bronze standard remained unchanged ${ }^{7}$, but there was a change in the monetary system associated with the beginning of the production of reformed bronze coins in the mints of Cyzicus, Thessaloniki, Alexandria (Egypt) and Chersonesus (Crimean Peninsula). In the period 518-527, the empire followed the monetary policy of the previous period, but judging by the coins discovered in Serdica, it can be assumed that there is a certain increase in their amount.

In Serdica the most numerous are the coins of 40 nummi, followed by those of 20 nummi, which are almost two times less than the large denomination. The number of the specimens of 10 and 5 nummi is equal (with a difference of 1 piece ${ }^{8}$ ), but is less than the number of the large denominations. As mints, the coins from Constantinople predominated, followed by coins from Nicomedia, Antioch and Cyzicus. From the period 518-522 the number of coins from Thessaloniki is smaller than the number of coins from the other mints. The coins of Justin I from Serdica, like those of Anastasius I, were severely worn out due to their prolonged use, which exceeded the reign of the emperor himself. The coins in circulation from the time of the emperors

\footnotetext{
${ }^{1}$ The sources related to the history of Serdica are analyzed by Ani Dancheva-Vasileva in articles and the summarizing work "History of medieval Sofia IV-XIV century" see Dancheva-Vasileva 2017.

2 Данчева-Василева 2017, 43 and ref. 67

${ }^{3}$ Божилов, Гюзелев 1999, 30-31

${ }^{4}$ Данчева-Василева 2017,44.

${ }^{5}$ Op.cit. 71.

${ }^{6}$ The discovered in Serdica coins identified from the period of Emperor Justin I suggest intensive trade in the city during the period, and the found emperor's seal, which is from a type unknown until, allows to reflect on the role of the city at that time. (Владимирова-Аладжова 2018, 125-131).

${ }^{7}$ Hahn, Metlich 2000, 15.

${ }^{8}$ The described coins are a collection of coins from various sites in Serdika. These are specimens, $90 \%$ of which are not cleaned and difficult to identify.
} 
Anastasius I and Justin I remained on the market even after the end of their rule. Some of the coins are in circulation for 30 to 100 years, retaining their status as a regular payment tool. The late Roman Empire sporadically demonetized its bronze coins by monetary reforms, which leads to instability, but is a prerequisite for these coins to remain on the market for decades.

Among the regular coins were found two imitations of folles of Justin I, which imitate the production of the mint of Constantinople from this period. The image on the averse is rough, and the inscription consists of unsuccessfully imitated individual letters. On the reverse side the $\mathrm{M}$ letter is the clearest, which determines the denomination of the coin. These coins, found together with the official ones used in the Byzantine state, show that they were accepted by the financial authorities as a regular payment tool. The imitation coins from the 6th - 7th century are found individually or in collective finds from this period ${ }^{1}$. It is assumed that different groups of imitations are produced in different centers, at different times, independently of each other ${ }^{2}$. Recently, in connection with an imitation discovered in Justiniana Prima, a thesis emerged that these are the local coins of the Romanized population in the region of Northern Illyricum, and as a confirmation of this are the imitations found in Naissus, Caričin Grad, Ulpiana ${ }^{3}$.

Two gold coins of Justin I are discovered in Serdica I - a solidus found at the eastern fortress wall and a tremis from the excavations at the northeastern tower. Adding the both tremises from the treasure described above, it is accepted that this emperor registered the largest number of «golds» in the city, with a total of 7 copies. The limited number of gold coins found in the city can be explained by the fact that the coins were exported by the population when facing the threat of taking the city by the enemies. At the same time, the fact that the role of gold coins in the late Roman and Byzantine economies remains controversial should not be eliminated, albeit from the point of view of the state that has a monopoly on coinage in order to replenish the treasury. This enables the emperor and the government to perform their duties by redistributing of the wealth between the court, the army and the aristocracy, on which the survival of the empire depends, and ensures that the wealth of the state will always return to the center. Therefore, the presence of gold coins, whether in treasure or single finds, reflects the needs of the state and its instruments rather than the existence of a market economy ${ }^{4}$. According to Guest, there is an alternative point of view according to which, the gold is becoming increasingly important in everyday transactions, but the

\footnotetext{
${ }^{1}$ Юрукова 1965, 21 - 23; Hahn 1976, 85 - 88; Жеков 1987, 22 - 25; Владимирова-Аладжова 1992, 73 - 92; Владимирова-Аладжова 1998, 70 - 75; Торбатов 2002 - 2003, 21 - 22; Филипова 2005, 85 - 87; Пенчев 2008, 57 - 67; Тенчова 2011, 100 - 114; Тенчова 2012, $619-640$.

${ }^{2}$ Михайлов 2007, 208; Пенчев 2008, 63

${ }^{3}$ Иванишевић, Стаменковић 2014, 169 - 176.

${ }^{4}$ Guest 2012, 106.
} 
question arises as to how the situation has developed over time under this type of governing ${ }^{1}$.

The new seal of Emperor Justin I presented in the article and the coins discovered by this ruler in Serdica show the significant role of the city during this period.

\section{Illustrations}

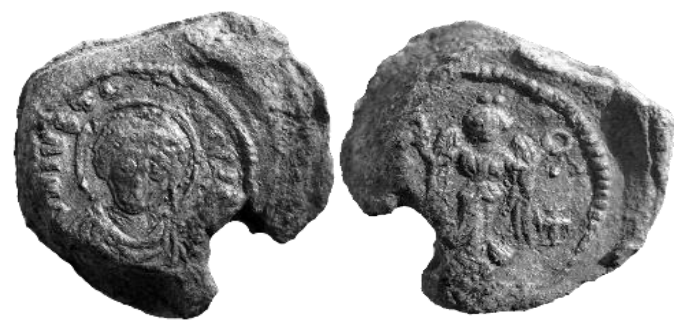

Fig. 1a, b. Seal of Emperor Justin I (518-527) Photo - D. Vladimirova-Aladzhova

\section{References}

Dancheva-Vasileva, A. (2008) Град Сердика и политическата история на ранна Византия през VI - 70-те години на V в. [The City of Serdica and the Political History of Early Byzantium in the $6^{\text {th }}-70 \mathrm{~s}$ of the $5^{\text {th }}$ century] Исторически преглед [Historical Review], 3-4, 2008, 2-23. [in Bulgarian].

Filipova, S. (2005) Късноантична монетна находка от с. Мърводол, Кюстендилско. - В: Монетите и банкнотите - възможни прочити. [Late antique coin find from the village of Murvodol, Kyustendil region. - In: Coins and banknotes - possible to read]. Юбилеен сборник в чест на ст.н.с. д-р Хр. Харитонов [Anniversary collection in honor of Assoc. Dr. Hr. Kharitonov]. B. Търново, 144-152. [in Bulgarian].

Guest, P. (2012) The Production, Supply and Use of Late Roman and Early Byzantine Copper Coinage in the Eastern Empire. - The Numismatic Chronicle, 172, 105131. [in English].

Gyuzelev, V. Bozhilov, Iv. (1999) История на Средновековна България VII - XIV $в е к$. [History of Medieval Bulgaria $7^{\text {th }}-14^{\text {th }}$ century]. 1, София. [in Bulgarian].

Hahn, W. (1976) Eine Gruppe byzantinischer Imitativprägungen nach Typen des 6. Jahrhunderts. Falschmünzerei oder offiziöse Fabrikation. - Ковањ и кованице античког средњовековног новца. Белград, 85-88. [in German].

Hahn, W. Metlich, M. (2000) Money of the Incipient Byzantine Empire (Anastasius I - Justinian I, 491 - 565). Vienna. [in English].

Iordanov, I. (2012) The diocese of Thrace (5th-7th c.) according to the sigillographic data. Arch. Bulg. 16.3 57-76. [in English].

${ }^{1}$ Ibidem. 
Ivanishevich, V. Stamenkovich, S. (2014) Имитаиијя полуфолиса Јустина II са Царичиног града (Justiniana Prima) [Imitation of the semi-follis Justin II with the Queen of the City (Justiniana Prima)] Numizmatičar 32, 2014, 169-176. [in Serbian].

Jones, A.H.M. (1964) The Late Roman Empire (284-602). [in English].

Mikhailov, St. (2007) Проблеми на ранновизантийската нумизматика (VI VII в.) в българските нумизматични изследвания. [Problems of the early Byzantine numismatics (VI - VII c.) In the Bulgarian numismatic researches] Известия на Регионален исторически музей - Велико Търново, [Proceedings of the Regional Historical Museum - Veliko Tarnovo] XXII, 2007, 207 - 218. [in Bulgarian].

Nesbitt, J. Morrisson, C. (2009) Cataloque of Byzantine Seals at Dumbarton Oaks and the Fogg Museum of Art. Vol. 6, Washington, D.C. [in English].

Penchev, Vl. (2008) Част от колективна находка с медни ранновизантийски монети от VI век от фонда на НИМ - София. [Part of a collective find with copper Byzantine coins from the $6^{\text {th }}$ century from the fund of National History Museum - Sofia] Известия на Националния исторически музей [Bulletin of the National History Museum], XIX, 2008, 57-67. [in Bulgarian].

Seibt, W. (1975) Resension von: Zacos G., Veglery,A. Byzantine Lead Seals, I. Byzantinoslavica, 36. [in English].

Sokolova, I.V. (2007) Печати византийских императоров. Каталог колекции. Государственный Эрмитаж. [Seals of Byzantine emperors. Collection catalog. State Hermitage]. Санкт Петербург. [in Russian].

Tenchova, A. (2011) Монетна циркулация през VI-VII век в земите на днешна Югоизточна България. [Coin circulation in the $6^{\text {th }}-7^{\text {th }}$ century in the lands of today's Southeastern Bulgaria]. Дисертация за получаване на образователната и научна степен „доктор“. Непубликувана. [Dissertation for obtaining the educational and scientific degree «Doctor». Unpublished]. София. [in Bulgarian].

Tenchova, А. (2012) Съкровище с ранновизантийски монети от с. Дюлино, община Бяла. - В: (Е. Паунов, С. Филипова, съствители) НРАКАЕОҮг $\Sigma \Omega T H P O E \Sigma \Theta A \Sigma Q N$. [Treasure with early Byzantine coins from the village of Dyulino, Byala municipality. - In: (E. Paunov, S. Filipova, co-authors)

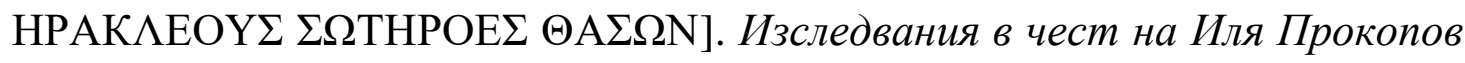
от приятелите и учениците му по случай неговата 60-годишнина. [Research in honor of Ilya Prokopov by his friends and students on the occasion of his 60th birthday]. Велико Търново, 2012, 619-640. [in Bulgarian].

Torbatov, S. (2002-2003) Ранновизантийско монетно съкровище от кастела Carea/Creas (провинция Скития). [Early Byzantine coin treasure from the castle Carea / Creas (province of Scythia)]. Нумизматика и сфрагистика. [Numismatics and Sphragistics]. 2002-2003, 20-27. [in Bulgarian]. 
Vladimirova-Aladzhova, D. (1992) Съкровище от медни византийски монети от VI в. [Treasure of copper Byzantine coins from the 6th century] Известия на музея Шумен [Proceedings of the Museum of Shumen], 7, 1992, 73-91. [in Bulgarian].

Vladimirova-Aladzhova, D. (1998) Още за варварските имитации в монетното обращение през VI в. [More about the barbaric imitations in the coin circulation in the 6th century] Нумизматика и сфрагистика [Numismatics and Sphragistics], 1998, 1, 70-75. [in Bulgarian].

Vladimirova-Aladzhova, D. (2018) Анонимен печат от края на V и началото на VI век открит в Сердика. В: „Българско царство“ Imperium Bulgariae в чест на 60 годишнина на дои. Георги Николов. [Anonymous seal from the end of the 5th and the beginning of the 6th century found in Serdica. In: «Bulgarian Kingdom» Imperium Bulgariae in honor of the 60th anniversary of Assoc. Prof. Georgi Nikolov]. София 2018, 125-131. [in Bulgarian].

Yourukova, J. (1965) Варварски подражания на византийски бронзови монети om VI в. [Barbaric imitations of Byzantine bronze coins from the $6^{\text {th }}$ century]. Археология [Archeology]. 1, 21-23. [in Bulgarian].

Zacos, G. Veglery, A. (1972) Byzantine Lead Seals. I. Basel. [in English].

Zhekov, G. (1987) Две имитации на византийски медни монети от VI в. [Two imitations of Byzantine copper coins from the 6th century] Нумизматика [Numismatics], 1, 22 -25. [in Bulgarian].

Латински извори за българската история I, [Latin Sources for Bulgarian History] 1958. [in Bulgarian]. 